\title{
Serum $\alpha$-macroglobulins in renal disease and preeclampsia
}

\author{
C. H. W. HORNE, J. D. BRIGGS, P. W. HOWIE, AND A. C. KENNEDY \\ From the University Departments of Pathology, Medicine, and Obstetrics and Gynaecology, Royal \\ and Western Infirmaries, Glasgow
}

SYNOPSIS The serum levels of $\alpha_{2}$-macroglobulin and pregnancy-associated globulin (another $\frac{\bar{\rho}}{\circ}$ $\alpha$-macroglobulin) have been measured by means of a radial immunodiffusion technique in (1) renali disease with and without proteinuria, (2) in age- and sex-matched controls, (3) in preeclampsia with. -1 and without proteinuria, and (4) in normal pregnant controls. There are significant increases ing $\alpha_{2}$-macroglobulin and pregnancy-associated globulin in renal disease accompanied by proteinuria ${ }_{2}$ but normal levels are found in renal disease without proteinuria. Compared with normal pregnancy, $\underset{ }{\supset}$ $\alpha_{2}$-macroglobulin is significantly raised in preeclampsia with proteinuria but normal in preeclampsia without proteinuria. In contrast, serum pregnancy-associated globulin is significantly reduced in preeclampsia both with and without proteinuria when compared with normal pregnancy.

Maclaren, Kelleher, and Reid (1961) have described in pregnancy a serum $\alpha_{2}$-globulin, now known to be a macroglobulin (Maclaren and Alper, 1970), and have referred to it as 'pregnancy-associated globulin' (PAG). However, it has also been found in the serum of a small number $(18 \%)$ of normal males and females (Maclaren, Reid, Konugres, and Allen, 1966). Since conventional serum $\alpha_{2}$-macroglobulin is known to be increased in the nephrotic syndrome (Schultze and Schwick, 1959; Steines and Mehl, 1966; Housley, 1968) and in preeclampsia accompanied by proteinuria (Horne, Howie, and Goudie, 1970a), it seemed likely that the serum levels of this other macroglobulin, PAG, might also increase in such diseases. Using a radial immunodiffusion technique we have determined the serum levels of $\alpha_{2}$-macroglobulin and PAG in 53 patients with various renal diseases and in agesex-matched controls, and also in preeclampsia with or without proteinuria and in normal pregnant controls.

\section{Subjects and Methods}

Sera were obtained from 53 patients ( 37 males, 16 females, mean age 34, range 13-64) who had a variety of acute and chronic renal diseases, usually some form of glomerulonephritis (Table I), of whom 44 had proteinuria. Hospital inpatients with no known renal disease were chosen as age- and sex-matched controls.

Received for publication 20 April 1972.

\begin{tabular}{|c|c|}
\hline Renal Disease & No. of Cases \\
\hline Acute and subacute glomerulonephritis & 7 \\
\hline Chronic glomerulonephritis & 6 \\
\hline Chronic proliferative glomerulonephritis & 9 \\
\hline Chronic pyelonephritis & 4 \\
\hline Focal glomerulonephritis & 5 \\
\hline Membranous glomerulonephritis & 6 \\
\hline Lupus nephritis & 3 \\
\hline Miscellaneous & 13 \\
\hline Total & 53 \\
\hline
\end{tabular}

Table I Clinical diagnosis in renal disease patients

Sera were also obtained from 37 preeclamptic patients (mean age 27.6 years, range 18-41, dura- 3 tion of pregnancy $37 \cdot 1$ weeks, range $30-41$ ), 13 witho proteinuria and 24 without proteinuria, and from 37 normal pregnant controls (mean age $27 \cdot 5$ years, 을. range 18-41, duration of pregnancy $37 \cdot 3$ weeks, range 30-41) matched for age, parity, and duration of pregnancy. Most of the pregnant patients had 0 been included in a previous study (Horne et al ${ }_{w}^{N}$ 1970a).

Proteinuria was estimated in the renal diseasec patients by the Biuret method and in the preeclamp $-\frac{-}{\mathbb{D}}$ tic patients by the Esbach technique.

All sera were stored at $-20^{\circ} \mathrm{C}$ for up to two years before assay. Antiserum to PAG was preparedo in rabbits by immunizing them with pregnan human serum, known to contain appreciabled quantities of this protein, in Freund's complete adjuvant and absorbing the resultant antiserum with human serum which did not contain this pros 
tein (Maclaren et al, 1966). Antiserum to serum $\alpha_{2}$-macroglobulin was prepared by the method of Goudie, Hor ne, and Wilkinson (1966).

Assay of serum $\alpha_{2}$-macroglobulin and PAG was carried out using a radial immunodiffusion technique (Horne et al, 1970a). Each serum was tested in duplicate and where appropriate the control serum was included in the same assay plate to minimize the effects of interplate variation (Thompson, Horne, Steele, and Goudie, 1969). Serum $\alpha_{2}$ macroglobulin concentration was calculated from a calibration curve with a solution of a freezedried, reconstituted pooled human serum containing $3,6,12$, and $18 \mathrm{~g}$ protein per $100 \mathrm{ml}$ and standardized with reference to a serum (Behringwerke AG) containing a known amount of this protein. Pregnancy-associated globulin concentration was expressed as a percentage of a pregnant human serum known to contain appreciable quantities of this protein.

The statistical analysis of results was carried out using either Student's t test or the $\chi^{2}$ test where appropriate.

\section{Results}

Table II shows a significant increase in serum PAG levels in renal disease with proteinuria (44 patients) compared with age- and sex-matched controls. Of the 44 patients with renal disease, only 18 have demonstrable PAG and of nine sera from renal disease without proteinuria none contain PAG $(P<0 \cdot 10)$. Of the 53 control sera, only eight contain PAG and this is significantly less than the number of PAG-positive sera in renal disease with proteinuria (18 out of 44$)(P<0.05)$. The mean urinary protein of the PAG-positive renal disease patients, $8.5 \mathrm{~g} / 24$ hours, is significantly more than that of the PAG negative, $4.0 \mathrm{~g} / 24$ hours $(\mathrm{P}<0.005)$. A highly significant increase in $\alpha_{2}$-macroglobulin is observed in the sera of renal patients with proteinuria compared with sera from controls and renal patients without proteinuria (Table II). There is a highly significant correlation $(\mathrm{P}<0.001)$ between $\alpha_{2}$-macroglobulin concentration and amount of proteinuria (Fig.) but no such correlation is noted between PAG and proteinuria. In addition there is no correlation between blood urea of creatinine clearance and the levels of $\alpha_{2}$-macroglobulin or pregnancy-associated globulin.

Table III shows significantly lower PAG levels in both preeclampsia groups compared with normal pregnancy, but there is no significant difference between preeclampsia with or without proteinuria. All preeclamptic and normal pregnant sera contain pregnancy-associated globulin. The difference in $\alpha_{-2}$-macroglobulin between normal pregnancy and preeclampsia without proteinuria falls short of significance. In preeclampsia with proteinuria (mean level $4.4 \mathrm{~g} / 100 \mathrm{ml}$ ), there is a significant increase in $\alpha_{2}$-macroglobulin compared with normal pregnancy and preeclampsia without proteinuria. No

\begin{tabular}{lccc}
\hline & Renal Disease & Controls \\
\cline { 2 - 4 } & $\begin{array}{l}\text { With Proteinuria } \\
(44 \text { patients })\end{array}$ & $\begin{array}{l}\text { Without Proteinuria } \\
(9 \text { patients })\end{array}$ & $3 \pm 12^{1}$ \\
\hline $\begin{array}{l}\text { Serum PAG (\% concentration) } \\
\text { Serum } \alpha-{ }_{2} \text { macroglobulin }\end{array}$ & $8 \pm 17^{1}$ & 0 & $328 \pm 116^{2}$ \\
\hline
\end{tabular}

Table II Serum PAG and $\alpha_{2}$-macroglobulin levels (mean $\pm S D$ ) in 53 patients with renal disease and in age-and sex-matched controls

${ }^{1}$ t test $P<0.05,{ }^{2}$ t test $P<0.0005$, ${ }^{3}$ t test $P<0.0125$

\begin{tabular}{|c|c|c|c|}
\hline & \multicolumn{2}{|l|}{ Preeclampsia } & \multirow[t]{2}{*}{ Normal Pregnancy } \\
\hline & With Proteinuria & Without Proteinuria & \\
\hline $\begin{array}{l}\text { Serum PAG ( } \% \text { concentration) } \\
\text { Serum } \alpha_{2} \text {-macroglobulin } \\
(\mathrm{mg} / 100 \mathrm{ml})\end{array}$ & $\begin{array}{l}81 \pm 62^{1} \\
601 \pm 215^{3}\end{array}$ & $\begin{array}{l}89 \pm 71^{2} \\
423 \pm 215^{3}\end{array}$ & $\begin{array}{l}127 \pm 73^{1 .} \\
467 \pm 154^{4}\end{array}$ \\
\hline
\end{tabular}

Table III Serum PAG and $\alpha_{2}$-macroglobulin levels (mean $\pm S D$ ) in 37 preeclamptic patients and in matched normal pregnant controls

\footnotetext{
${ }^{1}$ test $P<0.05 \quad$ it test $P<0.01$

${ }^{2}$ test $P<0.05 \quad{ }^{5} t$ test $P<0.10$

at test $P<0.0025$
} 


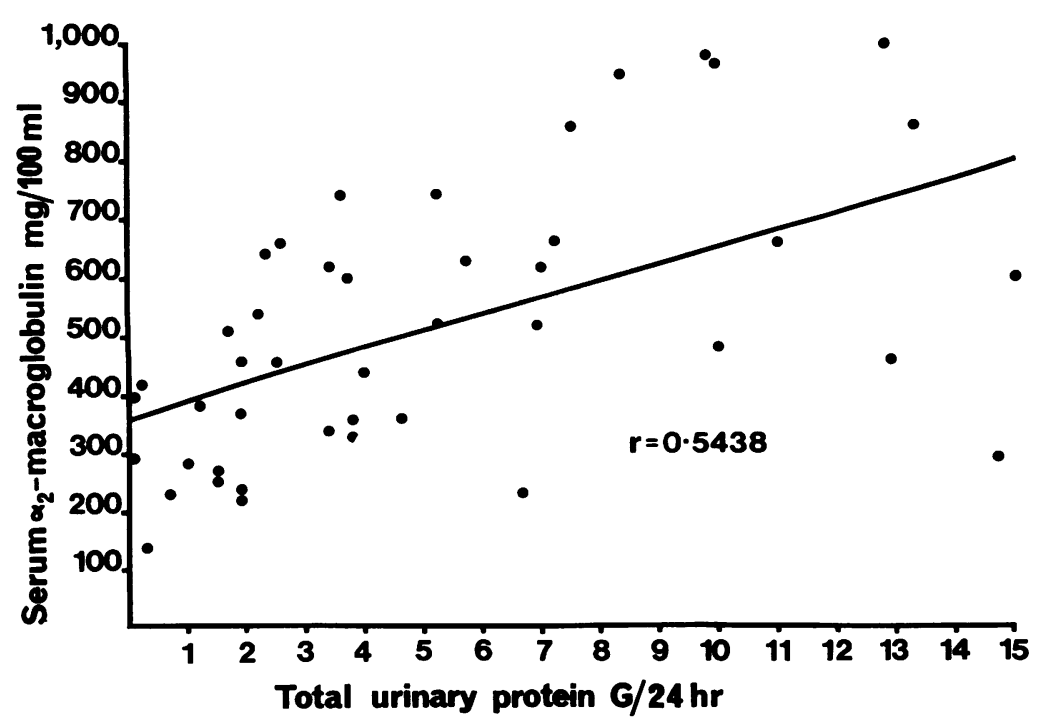

Fig. The relationship of serum $\alpha_{2}$-macroglobulin to total urinary protein.

significant correlation, however, is observed between the amount of proteinuria and PAG or $\alpha_{2}$-macroglobulin.

\section{Discussion}

The striking increase in serum $\alpha_{2}$-macroglobulin in the nephrotic syndrome is well known (Schultze and Schwick, 1959; Steines and Mehl, 1966; Housley, 1968). In our study those patients who had renal disease with associated proteinuria show an increase in serum $\alpha_{2}$-macroglobulin. In addition there is a highly significant correlation between $\alpha_{2}$-macroglobulin levels and the degree of proteinuria, a finding which does not appear to have been reported previously. Inspection of the Figure seems to indicate a proportional rather than a stepwise relationship between the amount of proteinuria and serum $\alpha_{2}$-macroglobulin and it would appear that raised $\alpha_{2}$-macroglobulin levels are not peculiar to the nephrotic syndrome. Although the reasons for the raised $\alpha_{2}$-macroglobulin levels are not clearly understood it would seem unlikely that marked increases in $\alpha_{2}$-macroglobulin could be attributed to non-specific factors such as diminution in plasma volume.

As anticipated there is an increase in serum PAG levels in patients with renal disease and associated proteinuria. Except for one case, however, the levels of PAG are low in comparison to those found in normal pregnancy. That PAG is demonstrable in the serum more often in renal disease than in other hospital patients lends support to the suggestion that this macroglobulin may be present in allo human sera but in such minute quantities that its presence is difficult to detect using conventiona: immunodiffusion techniques (Maclaren et al, 1966) Our failure to demonstrate a correlation between $\mathbb{Q}$ PAG and the amount of proteinuria may be due to the unsuitability of our radial immunodiffusion technique for the accurate measurement of very low levels of pregnancy-associated globulin.

In a previous study (Horne et al, 1970a) we demonstrated significantly lower $\alpha_{2}$-macroglobulino levels in 13 patients with preeclampsia unaccompanied by proteinuria compared with those in normal pregnancy but in the present study we haveo failed to confirm this finding in an extended group of 26 patients. The raised $\alpha_{2}$-macroglobulin levels in preeclampsia with proteinuria have been described in our previous study (Horne et al, 1970a). In preeclampsia we have found no correlation between N $\alpha_{2}$-macroglobulin and the amount of proteinuria. The low serum PAG levels in preeclampsia unac- 0 companied by proteinuria are of interest and couldw be the result of decreased production of oestrogen and/or progestogen which are thought to occur ino this disease (Klopper, 1968), particularly since ito has been clearly shown that the levels of this protein? increase following the administration of combined oestrogen/progestogen oral contraceptives (Maclaren? et al, 1966). Unlike $\alpha_{2}$-macroglobulin serum PAG levels do not increase in preeclampsia with pro- $\frac{\mathbb{D}}{\Omega}$ teinuria.

Although both pregnancy and the administration of oestrogen/progestogen oral contraceptives resulto 
in raised serum levels of $\alpha_{2}$-macroglobulin (Horne, Howie, Weir, and Goudie, 1970b) and PAG, it is clear that in renal disease and preeclampsia these serum $\alpha$-macroglobulins behave in a dissimilar fashion.

We wish to thank Dr C. A. Alper and Dr J. A. Maclaren for supplying the antiserum to pregnancyassociated globulin. This study was supported by a grant from the Secretary of State for Scotland.

\section{References}

Goudie, R. B., Horne, C. H. W., and Wilkinson, P. C. (1966). A simple method for producing antibody specific to a single selected diffusible antigen. Lancet, 2, 1224-1226.

Horne, C. H. W., Howie, P. W., and Goudie, R. B. (1970a). Serum alpha ${ }_{2}$-macroglobulin, transferrin albumin, and IgG levels in preec'ampsia. J. clin. Path., 23, 514-516.
Horne, C. H. W., Howie, P. W., Weir, R. J., and Goudie, R. B. (1970b). Effect of combined oestrogen-progestogen oral contraceptives on serum-levels of $a_{2}$-macroglobulin, transferrin, albumin and IgG. Lancet, 1, 49-51.

Housley, J. (1968). Alpha, macroglobulin levels in disease in man. J. clin. Path., 21, 27-31.

Klopper, A. (1968). The assessment of feto-placental function by estriol assay. Obstet. gynec. Surv., 23, 813-838.

Maclaren, J. A., and Alper, C. A. (1970). Unpublished observations.

Maclaren, J. A., Kelleher, P. C., and Reid, D. E. (1961). Circulating antigens in pregnant humans. In First Rochester (N.Y.) Trophoblast Conference, edited by H. A. Heide, p. 225.

Maclaren, J. A., Reid, D. E., Konugres, A. A., and Allen, F. H., Jr. (1966). Pa 1, a new inherited alpha-2 globulin of human serum. Vox Sang. (Basel), 11, 553-560.

Schultze, H. E., and Schwick, G. (1959). Quantitative immunologische Bestimmung von Plasmaproteinen. Clin. chim. Acta, $4,15-25$.

Steines, W. J., and Mehl, J. W. (1966). The elevation of alpha ${ }_{2}-$ macroglobulin and trypsin binding activity in nephrosis. J. Lab. clin. Med., 67, 559-565.

Thompson, A., Horne, C. H. W., Steel, H., and Goudie, R. B. (1969). Concentrations of serum $a_{2}$-macroglobulin in twins. Nature (Lond.), 221, 289-290. 